\title{
Vocational Learning Design for Women in Rural Areas in Indonesia
}

\author{
K Sumardi, A Djohar \\ Department of Mechanical Engineering Education \\ Universitas Pendidikan Indonesia \\ Bandung, Indonesia \\ kaminsumardi@upi.edu
}

\begin{abstract}
This research aims to generate a vocational learning design for women in rural areas. The vocational learning in the design includes knowledge, attitudes, and skills which are needed by learners to be applied in their lives. Three methods were used in the design of the vocational learning, namely: regenerated frerian literacy through empowering community techniques (REFLECT), language experience approach (LEA) and participatory rural appraisal (PRA). The research used quasi-experiment with the research and development approach. Four research instruments were employed in the study: direct observations, interviews, documentations and tests. Thirty women from rural areas were taken as participants of the research. The findings of the research indicate that vocational education has encouraged the participants to have motivations and awareness of the importance of learning. Thus, they become more active in classrooms, understand learning materials better, and have lifeskills. Such learning is useful for their lives. Based on the results, it can be argued that vocational learning is effective for the learning of women in rural areas. It inspires them to be better individuals. The vocational learning meets the learning need of women in rural areas by giving them lifeskils.
\end{abstract}

Keywords—vocational, rural, lifeskill, illiteracy, multimethod

\section{INTRODUCTION}

Along with the increase of the need of the society for education, vocational education plays an important role in the empowerment of women in rural areas. Vocational education can help women be aware of education, experience it and develop themselves in accordance with their roles and capabilities. Furthermore, education is one of human basic rights. In Indonesia, the majority of the population is women [1]. However, most of them do not have access to education, including vocational education. Various factors contribute to this condition, such as low income, low awareness of the importance of education, the big number of family members, and their inability to manage problems and compete in life (life competition). Such factors may cause dropouts; they might increase the number of uneducated citizens.
Vocational education has a positive impact on the social, economic, and cultural aspects of life. It can be employed as a key instrument for the betterment of the society. Vocational education is an approach to develop individuals' ability to apply knowledge and attitude, to think, to observe and listen, and to talk and act based on their orientation of life [2]. Not only does vocational education develop knowledge, attitude, and skills, it also encourages the application of the knowledge, attitude, and skills acquired through the learning process. Philosophically, vocational education is an ideology as it consists of ideas, trust, and attitudes. Such aspects form the way the society perceives vocational education. The ideology will influence individuals in a community, encouraging them to participate in vocational learning processes. Therefore, the ideology which is applied in vocational education programs is the learning ideology.

Vocational education should focus on lifeskill. It should be designed to include curricula which develop knowledge, attitudes, and skills. It is expected that vocational education programs can solve problems faced by women in rural areas, particularly those related to their jobs and the value of their education. The curriculum of vocational education focuses on the apprenticeship of learning, which supports the life of learners. It is a catalyst for learners to participate actively in social, cultural, politic and economic activities as well as the empowerment of the society. Vocational education is a framework for long-life learning. Furthermore, vocational education emphasizes the abilities required to adapt to new/different circumstances in the society. It employs a multientry-exit system and multi-meaning, and is oriented toward the acculturation, empowerment, and formation of characters, personalities, and lifeskills.

Vocational education aims to produce learners who are intelligent, creative, innovative, and competitive; the learners are confident in their efforts to be successful in their lives. They also have the ability to apply knowledge, technology and art with regard to their needs, so that the ability is useful for the prosperity, tranquility, and safety of themselves, their family, 
the environments and the society in which they live [3]. The concept of vocational education The concept of vocational education continues to grow and has better approaches than the previous programs. The approaches are: (1) emphasizing the basic skills of individuals, (2) emphasizing the active and creative involvement of learners, (3) building knowledge and experience, as well as paying attention to learners, (4) focusing on learning materials which have been developed, (5) ensuring learning processes that are responsive and relevant to social contexts, (6) ensuring that the process of learning occurs in any contexts, not only in classrooms. Vocational education is based on two fundamental principles: longlife education and longlife learning.

REFLECT method (Regenerated Frerian Literacy through Empowering Community Techniques), which refers to the empowerment of the community by instructors. This reflects the integration of vocational activities and community empowerment [4]. REFLECT is a method which integrate practices and participative learning, which facilitates the critical perspectives of learners toward their environments. On the other hand, Language Experience Approach (LEA) is an experience-based approach which is used to motivate learners to design their own learning materials based on contents they want to learn. The LEA method is employed to reduce learners' dependence on published books or modules. The effectiveness of this method depends on the capability of instructors in directing and guiding learners in the learning processes. Participatory Rural Appraisal (PRA) is a method of rural assessment which enables members of a community to share, add/develop, and analyse knowledge. PRA method can be used to empower members of a community through assessments of challenges or problems found in contexts where learners live [5].

So far, vocational education has only been conducted at schools and training institutions in cities. It is done by using single method, in which instructors become the centre (teachercentred). Under this method, the vocational education only uses books as learning references, which are still limited. After the process of learning ends, many learners are not able to apply the knowledge which they get to make their lives better. Thus, learning has not raised their awareness, as well as their empowered and independent spirit in the community [6].

Vocational learning should be designed to help learners acquire knowledge, attitudes, and skills in accordance with their needs. Learning should be in line with the resources available in the environment of the learners. The vocational education developed integrates the methods of REFLECT, LEA, and PRA to support the life of women, particularly those in rural areas.

\section{METHOD}

This research employed a quasi-experimental design with the research and development approach. It was conducted in some stages: a pilot study to gather early data, which include empirical and theoretical data; the formulation of a conceptual model of vocational education programs; and validation through discussions and expert judgment. The effectiveness of the vocational education model was measured using three methods: REFLECT, LEA, and PRA through field testing. One-group posttest only design was employed to test the model. Based on the test, the model was validated, revised and formulated to be a final model. Research data were collected using observations, interviews, documentations and tests, which were conducted for three months from August to October 2014. The research involved 30 women living in the village of Kertasari, sub-district Pebayuran, Bekasi.

\section{RESULTS}

As the basic part of learning, the participants were introduced to thematic knowledge, attitude, and skills which they are familiar with. At this stage, learners were given practices with regard to the three perspectives, particularly for the purpose of introducing and understanding. Additionally, they were given practice books. To explore knowledge, attitude, and skills, they were encouraged to use the language which they used daily (daily language). For applying the knowledge, attitude, and skills, structured practices and books were given to the participants. In each meeting, discussions in small groups were conducted to discuss the materials given. In the meetings, new words or sentences from their language were used. The words or sentences are related to their jobs and habits.

The results of the learning of knowledge, attitudes, and skills which have been achieved by the participants are based on the required competence and alocated time. Their knowledge, attitudes, and skills have increased, compared to their knowledge, attitudes and skills prior to the study. In the learning process, they practiced hard as they had stopped learning since quite a long time ago. At the first stage, they were unconfident; however, with the guidance of the instructors and their willingness to learn, they could overcome their feeling. Their achieved knowledge, attitudes, and skills were satisfying, in accordance with the expected competency and time allocated. Based on the results, it can be argued that their learning has met the learning standard, reflected by the learners' activities in writing job descriptions and skill-needs which support their jobs. With regard to lifeskills, at the early stage the participants experienced difficulties. However, they were asked to use all of their potential, including their experiences and habits. Through such a way, it was easier for the learners to understand the materials as they only needed to develop the knowledge which they had already known. In the lifeskill-learning process, the participants were given activies based on the themes, adjusted themes, or particular themes from their lives. The activities were aimed at helping the learners understand.

The results of the lifeskill learning were applied by the participant to their jobs. For example, sellers used their skill to calculate unit weight (gram, ounce, and kilogram), and distance (metre and kilometre) which are directly related to their jobs and lives. Additionally, they could calculate dates, months, and years. Their communication skill has improved, indicated by their ability to answer questions. Learners have already have the ability to raise questions and could understand the keypoints of reading materials given to them and understand the daily assignments. 
Evaluations were done at the end of every session. They were always given take-home assignments. At the beginning of every meeting, a quiz/test was conducted to measure the learners' ability in their learning. The test was in the form of a written test or practice. In the written test, a question or statement related to knowledge, attitude, and skills, was given to the participants.

After all materials were delivered within 114 hours of lessons, competency test was done. There are two skills which have to be acquired by the learners: the competency standard of graduates (SKL) and vocational skills. SKL is a graduates' skill qualification which covers attitude, knowledge, and skills. Vocational competency test is a set of formal vocational competency which has to be shown by learners through the results of their learning in every sub-vocational ability (knowledge, attitude, skills and lifeskills) in every level. The achieved score (Table 1) is an indicator of the learners' successful achievement in vocational learning. The learners received satisfying scores after taking part in the vocational learning which employed multi methods.

\section{TABLE 1. THE RESULTS OF COMPETENCY TESTS}

\begin{tabular}{lll}
\hline No. & Assessment Components & Score \\
\hline 1 & Average score of knowledge competency & 95 \\
2 & Average score of attitude competency & 90 \\
3 & Average score of skill competency & 80 \\
4 & Average score of lifeskill competency & $\cdot 88$ \\
5 & Average score of early capability & 49 \\
6 & Average score of final capability & 88 \\
7 & Average score of the increase of capability & 39 \\
\hline
\end{tabular}

The impact of vocational learning (Table 2) can be grouped into two categories: first, the impact on knowledge and skill; second, the impact on the use of the learning results in the learners' lives. The impact of basic vocational learning on knowledge, attitude, and skills can be observed from the results of the tests. The impact of the use of the learners' learning in their lives is more focused on attitudes and mindset. The impact of their learning can be seen when the learners talked about their daily activities. As a result of the learning process, their attitudes and mindsets are influenced by the increase of their knowledge, attitude, and skills. The results of the observations during the study indicate positive impacts on their lives.

TABLE 2. THE IMPACT OF VOCATIONAL LEARNING RESULT

\begin{tabular}{ll}
\hline Learners' Professions & $\begin{array}{l}\text { Application of Learning Results in } \\
\text { Life (\%) }\end{array}$ \\
\hline Farmer & 85 \\
Small traders & 90 \\
$\begin{array}{l}\text { Housewives } \\
\text { working) }\end{array}$ & 70 \\
\hline
\end{tabular}

\section{DISCUSSION}

Vocational learning is a key element in the development of human resources, particularly women. Vocational education for women in rural areas becomes one of important issues due to the large number of woman in the rural areas. Furthermore, women's access to education has not been sufficiently available. An effective vocational learning design using multimethods is needed. Vocational education design combining REFLECT, LEA, and PRA in vocational learning was constructed based on theoretical and empirical studies. The combination of the three methods was designed based on the characteristics of learners, particularly women from rural areas [7].

A learning method is an important factor in the process of delivering knowledge or contents. Through an effective learning method, it is expected that learning materials can be delivered effectively so that learners can understand them. It is obvious that learning method cannot stand by itself; it should be accompanied with many other learning components. All components should be integrated to generate effecting learning. Furthermore, the components should be matched with the purpose of the learning, the curriculum, instructors, materials, methods, techniques, media, and evaluations.

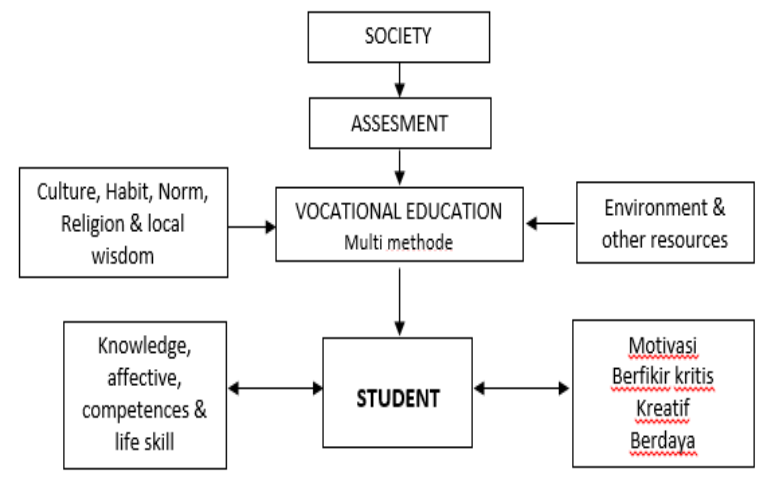

Fig 1. Vocational learning scenario with multi-method

The development of vocational learning method using multi-method was done by designing a scenario suitable with the conditions of learners and the principles of adult learning. The design of the scenario was based on learners' characteristics and the characteristics of the learning method. After the scenario had been designed, learning processes were done in accordance with the scenario (Fig 1). In the implementation, the scenario could be changed or adjusted to suit the condition in the field. The adjustment was technical in nature, aimed at ensuring the effectiveness of the learning process [8].

During vocational learning, some strengths emerged and were identified. The strengths are the internal resources of the community which becomes an advantage for the implementation of vocational learning. The internal resources include: organizations, human resources, and learning facilities. Rural communities are earthy/humble communities; most members of the rural communities work as farmers. Close observations of the rural community and learners reveal the 
strengths of the learners and communities. Silent culture can be found among women in the rural areas. Fatalism, which refers to the state of being submissive, becomes the cause of such a culture [9]. However, the women have potential energy to work for their families. They have not been empowered as members of the community who have potentials and motivations to develop themselves.

The potentials which should be empowered include public figures who support the learning by providing venues and facilities for the learning process. Besides that, the public figures also supported the learners. Village government officials and Education UPTD also supported the learning process by being motivators for the learners. Volunteers involved in this study, who were local people from the village, had teaching experience. The instructors also become a supporting factor which can potentially be developed through instructor training programs. Another potential was the venue used for the vocational learning. Public facilities for reading were available, although the available books were limited. A simple form of administration management has been employed.

Another advantage of vocational learning using multimethod is that the learning suits the characteristics of the learners. The sequence of the method application becomes a supporting strength which accelerates the understanding of learners. The time for achieving the competency was in accordance with the allocated time; thus, learning can be regarded effective. The implementation stages of the method were in accordance with the development stages of the learners, supported by the use of learning media [10].

Some weaknesses were identified during the implementation of the learning process. One of the main weaknesses is funding. However, such a weakness had been addressed by collaborative contribution. Available facilities, such as classrooms and TBM rooms, had not been used optimally. The rooms were often unused and there were not many available learning facilities/instruments in the classrooms. The reading facilities (TBM) need more books in order to be used as references by the community. Furthermore, in terms of management, the administration was simple.

The support from public figures was motivational, in the form of moral support. They had not been able to realize the support for actual learning because of their limited ability. Such a support should be developed into real and continuous activities. Therefore, agents of change from outside the village are needed to improve the learning process. Motivators are needed to improve their awareness of the importance of learning and encourage them to learn [11]. Vocational learning depends on instructors. The available instructors had not received required trainings; therefore, their ability was still insufficient. The number of instructors was limited and they had not met the qualification of good instructors.

The above analysis indicates the advantages of vocational learning using multi-method. The identified weaknesses of the implementation of the single method have been solved, although there are some aspects that still need to be improved. The threats identified in this study include the limited number of instructors, particularly those who have mastered the concept of vocational learning. Instructors must understand the implementation strategy of the integration of the three methods in vocational learning processes. Furthermore, the instructors much be able to implement the vocational learning scenario in classrooms.

\section{CONCLUSION}

It can be concluded that vocational learning by combining the REFLECT, LEA, and PRA methods is effective for improving learners' vocational skills. The basic vocational ability includes knowledge, attitudes, and skills which can be used in the learners' lives (lifeskill). The results of vocational learning can be applied in their lives, thus, become useful for the learners. Therefore, women have become agents of change in their families and communities, particularly with regard to the importance of vocational education for their lives.

\section{ACKNOWLEDGMENT}

The researcher would like to thank the general director of formal and non-formal education for funding the project, village officials of Kertasari and sub-district Pebayuran who have granted the permit for conducting the study, and instructors who have facilitated the learning process.

\section{REFERENCES}

[1] Biro Pusat Statisik 2014 Statistik Indonesia. (Jakarta: Biro Pusat Statistik Indonesia)

[2] Kuswana W S 2013 Dasar-dasar Pendidikan Vokasi dan Kejuruan (Bandung: Alfabeta)

[3] Paryono 2013 Anticipating ASEAN Economic Community 2015: Regional initiatives on human resources development and recognition of professional qualifications. In: TVET@Asia, issue 2, p.1-8. Online: http://www.tvet-online.asia/issue2/paryono_tvet2.pdf

[4] Archer D and Cottingham S 2005 Reflect Mother Manual: Regenerated Freirean Literacy Through Empowering Community Techniques (London: ACTIONAID)

[5] Adimihardja K and Hikmat H 2004 Participatory Research Appraisal: Pengabdian dan Pemberdayaan Masyarakat (Bandung: Humaniora)

[6] Tripney J S and Hombrados J G 2013 Technical and vocational education and training (TVET) for young people in low and middleincome countries: a systematic review and meta-analysis. Empirical Research in Vocational Education and Training, 5 (3)

[7] Shan H, Liu, Z \& Li, L 2015 Vocational training for Liushou women in rural China: development by design. Journal of Vocational Education \& Training, 67 (1), p.11-25

[8] Alias M and Hassan R 2013 TVET agency-industry collaborations: addressing diversity. In: TVET@Asia, issue 1, 1-14. Online: http://www.tvet-online.asia/issue1/alias_hassan_tvet1.pdf

[9] Freire P 2000 Politik Pendidikan, Kebudayaan, Kekuasaan dan Pembebasan (Yogyakarta: REaD and Pustaka Pelajar)

[10] Haasler S R and Gottschall K 2015 Still a perfect model? The gender impact of vocational training in Germany. Journal of Vocational Education \& Training, 67 (1), p.78-92

[11] Hinzen H 2013 Lifelong Learning for All-A potential global goal for the post 2015 education and development agendas. Adult Education and Development. No. 80 